\title{
A Study of Radium Concentration and Radon Exhalation Rate in Soil Samples from Kassala Town, Sudan Using SSNTDs
}

\author{
Abd-EImoniem A. Elzain ${ }^{1,2}$, Y. Sh. Mohammed ${ }^{2,3}$, Khidir Shaib Mohamed ${ }^{4,5}$, A. M. Mohamed-Ali ${ }^{6}$ \\ ${ }^{1}$ Department of Physics, University of Kassala, Kassala, Sudan \\ ${ }^{2}$ Department of Physics, College of Science \& Art, Qassim University, Oklat Al-Skoor, Saudi Arabia \\ ${ }^{3}$ Department of Physics, College of Education, Dalanj University, Dalanj, Sudan \\ ${ }^{4}$ Department of Mathematics, College of Science, Dalanj University, Dalanj, Sudan \\ ${ }^{5}$ Department of Mathematics, School of Mathematical Sciences, Dalian University of Technology, Dalian, PR China \\ ${ }^{6}$ Department of Geophysics, College of Earth Sciences and Mining, Dongola University, Dongola, Sudan
}

Email address:

Abdelmoniem1@yahoo.com (Abd-Elmoniem A. Elzain), moniemelzain1@gmail.com (Abd-Elmoniem A. Elzain)

\section{To cite this article:}

Abd-Elmoniem A. Elzain, Y. Sh. Mohammed, Kh. Sh. Mohamed, A. M. Mohamed-Ali. A Study of Radium Concentration and Radon Exhalation Rate in Soil Samples from Kassala Town, Sudan Using SSNTDs. American Journal of Physics and Applications.

Vol. 4, No. 4, 2016, pp. 84-89. doi: 10.11648/j.ajpa.20160404.11

Received: March 1, 2016; Accepted: March 2, 2016; Published: June 20, 2016

\begin{abstract}
In this work, we are presenting the results of radium concentration, surface and mass radon exhalation rates for a number of 209 soil samples collected from different locations of Kassala town, Sudan, by using the can technique, containing CR-39. The values of radium concentrations from soil samples were found to be ranging from 3.9 to $34.2 \mathrm{~Bq} \cdot \mathrm{kg}^{-1}$, with an average of $16.3 \pm 1.6 \mathrm{~Bq} \cdot \mathrm{kg}^{-1}$. The surface and mass exhalation rates of radon were found to be from 0.84 to $7.35 \mathrm{~Bq} \cdot \mathrm{m}^{-2} \cdot \mathrm{h}^{-1}$ and 17 to $148 \mathrm{mBq} \cdot \mathrm{kg}^{-1} \cdot \mathrm{h}^{-1}$, with an averages of $3.50 \pm 0.35 \mathrm{~Bq} \cdot \mathrm{m}^{-2} \cdot \mathrm{h}^{-1}$ and $70 \pm 7 \mathrm{mBq} \cdot \mathrm{kg}^{-1} \cdot \mathrm{h}^{-1}$, respectively for the studied soil samples. From the results of this study we found that, there was a good correlation between radium concentration and radon exhalation rates in soil samples. The values of radium concentration determined in soil samples are less than the permissible value of $370 \mathrm{~Bq} \cdot \mathrm{kg}^{-1}$ recommended by Organization for Economic Cooperation and Developments, which is acceptable for safe use. Thus, results reveal that the area is safe as far the health hazard effects are concerned. Finally we compare our results with similar findings in different regions of Sudan and among other Countries.
\end{abstract}

Keywords: Radium Concentration, Radon Exhalation Rate, Passive Diffusion Radon Dosimeters, Soil

\section{Introduction}

Radon, a gaseous product of uranium decay series, is odorless, colorless and tasteless. However, it can change the physical properties of the surrounding medium. Its half-life allows it to migrate long enough to travel long distances and accumulate indoors. The inhalation of radon and its daughter products can cause a significant health hazard when present in enhanced levels in the enclosed indoor environments like a human dwelling [ 1 - 6]. The radon concentration in the ground depends on the radium content of the soil and the emanation power of soils and rocks $[7,8]$.

Radium is a solid radioactive element under ordinary conditions of temperature and pressure. Radium is a decay product of uranium in the naturally occurring uranium series. The rate at which radon escapes from soil into the surrounding air is known as radon exhalation rate of the soil. This may be measured by either per unit area or per unit mass of the soil. The measurement of radon exhalation rate in soil and building materials is helpful to study radon health hazard [9, 10]. It was recorded that radon exhalation rate studies are important for understanding the relative contribution of the material to the total radon concentration found inside the dwellings [11, 12].

Among many factors affecting radon exhalation, one of the most important is radium content of the bedrock or soil [13]. Being aware of the hazardous effects of radon exhalation on human health, it was necessary to conduct measurements of radium content in the soil. Higher values of radium in soil 
contribute significantly in the enhancement of environmental radon [14].

However, radon exposure shows an extreme variation from location to location and depends primarily on the exhalation rate of radon from the soil [15].

Since radium present in the soil is the main source of indoor radon, the estimation of radium content along with the radon exhalation rate in the soil was carried out.

\subsection{Aim of the Study}

This study was undertaken for the purpose of estimating the radium concentration and radon exhalation measurements in soil samples from Kassala town in the eastern part of Sudan, by using can technique containing SSNTDs of type CR-39.

This survey is conducted to continue our previous works of measuring indoor radon concentrations [16-21], radon and radium concentrations and radon exhalation rates from soil samples from various locations in Sudan [10, 15, 22-24], radon concentration from water samples $[25,26]$ and building materials [9].

\subsection{Description of the Study Area}

Kassala town which includes the area under study is the capital of Kassala State. It is located in the eastern part of Sudan, very closed to Ariterian boarder see Fig. 1 . The town is located at latitude of $15^{\circ} 27^{\prime} \mathrm{N}$ and longitude $36^{\circ} 24^{\prime} \mathrm{E}$ and at a distance of $625 \mathrm{~km}$ from Khartoum. The Gash seasonal river, divides the town into tow semi equal parts eastern and western residential areas. The eastern extent of the town is bounded by two north south oriented inselbergs of which Jebel Kassala (Kassala granitic hills). The soils are moderately well drained, slowly permeable.

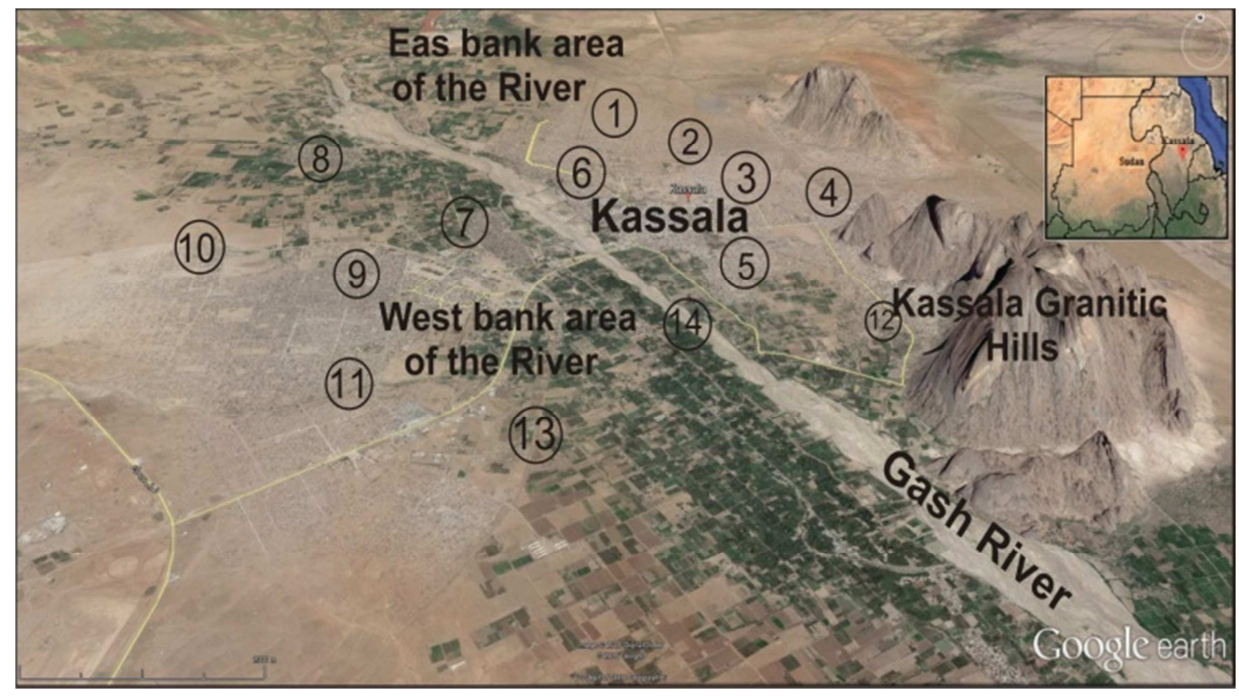

Figure 1. The locations of soil samples in the study area at Kassala town, Sudan.

\section{Measurement Technique}

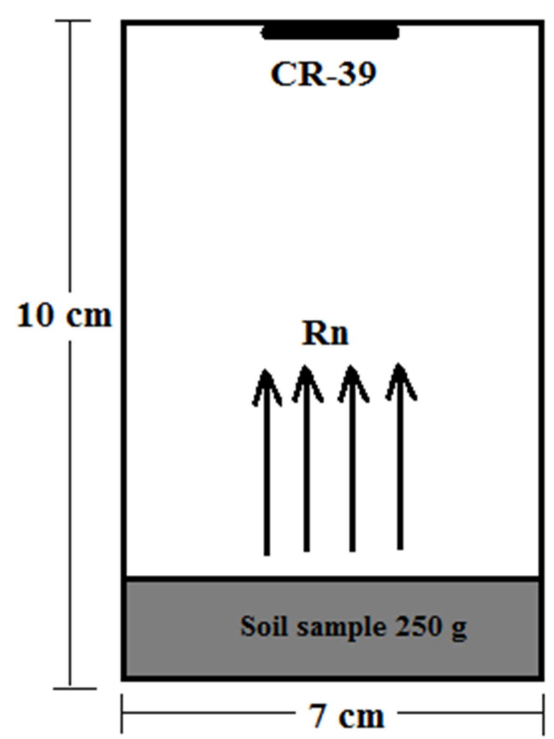

Figure 2. The passive diffusion radon dosimeter used in the study.
Time-integrating passive diffusion radon dosimeters were [27-29] employed for the measurement of radium concentration, surface and mass radon exhalation rates from soil samples in various locations of Kassala town, see Fig. 2.

An amount of 6 kilograms from each sample was collected under the depth of $30 \mathrm{~cm}$ within $1.5 \mathrm{~m}$ of the foundations of the dwelling in selected locations, the samples were dried in a temperature controlled furnace (oven) at a temperature degree of $100 \pm 0.1^{\circ} \mathrm{C}$ for $24 \mathrm{~h}$ to ensure that moisture is completely removed, then the samples were crushed to a fine powder and sieved through a small mesh size to remove the larger grains size and render them more homogenous. About $250 \mathrm{~g}$ of each sample was placed in a plastic can of dimensions of $10 \mathrm{~cm}$ in height and $7.0 \mathrm{~cm}$ in diameter [9, 10, 24, 29].

A piece of CR-39 detector of size $2 \times 2 \mathrm{~cm}$ was fixed on the top of inner surface of the can, in such a way, that it is sensitive surface always facing the sample, see Fig. 2.

The can is sealed air tight with adhesive tape and kept for exposure of about three months. During exposure period, the detector is exposed freely to the emergent radon from the sample in the can so that it could record alpha particles resulting from the decay of radon in the remaining volume of 
the can. After that, the dosimeters were separated from the sample cup, collected and chemically etched in a $30 \%$ solution of $\mathrm{KOH}$, at $700 \pm 0.10^{\circ} \mathrm{C}$ for a period of 9 hours. The resulting $\alpha$ tracks were counted under an optical microscope of magnification $400 \mathrm{X}$.

The radium concentration in soil was calculated using the relation: $[9,30-32]$ :

$$
\mathrm{C}_{\text {Radium }}=\frac{\rho \mathrm{hA}}{\mathrm{KT}_{\mathrm{e}} \mathrm{M}}
$$

Where: $\mathrm{C}_{\text {Radium }}$ is the effective radium content of soil sample $\left(\mathrm{Bq} \cdot \mathrm{kg}^{-1}\right), \rho$ is the track density (tracks per $\left.\mathrm{cm}^{2}\right), \mathrm{A}$ is the surface area from which radon is exhaled $\left(\mathrm{m}^{2}\right)$ and $\mathrm{M}$ is the mass of the sample $(\mathrm{kg}), \mathrm{h}$ is the distance between the detector and the top of the soil sample (m), $\mathrm{K}$ is the calibration constant which was determined previously to be: $\mathrm{K}=3.746 \times 10^{-3}$ tracks. $\mathrm{cm}^{-2} \cdot \mathrm{h}^{-1}$ per Bq. $\mathrm{m}^{-3}[9,15], \mathrm{T}_{\mathbf{e}}$ is the effective exposure time, which is related to the actual exposure time $\mathrm{T}$ by the relation [15].

$$
\mathrm{T}_{\mathrm{e}}=\mathrm{T}-1 / \lambda\left(1-\mathrm{e}^{-\lambda \mathrm{T}}\right)
$$

In order to measure radon concentration and its exhalation rate, using the sealed can technique, the radon exhalation rate in terms of area $E_{A}\left(B q . m^{-2} \cdot h^{-1}\right)$ is calculated by using Equation 3, as: [9, 31]:

$$
\mathrm{E}_{\mathrm{A}}=\frac{\lambda \mathrm{VC}}{\mathrm{A}\left[\mathrm{T}+\lambda^{-1}(\exp (-\lambda \mathrm{T})-1)\right]}
$$

Moreover, the radon exhalation rate in terms of mass EM $\left(\mathrm{mBq} \cdot \mathrm{kg}^{-1} \cdot \mathrm{h}^{-1}\right)$ is determined by Equation $4:[9,15]$ :

$$
E_{M}=\frac{\lambda V C}{M\left[T+\lambda^{-1}(\exp (-\lambda T)-1)\right]}
$$

Where: $\mathrm{V}$ is the hollow holder volume $\left(\mathrm{m}^{3}\right), \lambda$ is the radon decay constant $\left(\mathrm{h}^{-1}\right), \mathrm{C}$ is the integrated radon exposure as measured by CR-39 plastic track detector $\left(\mathrm{Bq} \cdot \mathrm{m}^{-3} \cdot \mathrm{h}\right)$.

\section{Results and Discussion}

In this work, the values of radium concentration and radon surface and mass exhalation rates are determined in a number of 209 soil samples collected from different locations of Kassala town in Sudan.

Table 1 represents the radium concentration values and the radon exhalation rates (surface and mass) for soil samples in Kassala town locations.

The maximum and minimum radium concentration values were found to be $34.2 \pm 2.3 \mathrm{~Bq} \cdot \mathrm{kg}^{-1}$ and $3.9 \pm 0.4 \mathrm{~Bq} \cdot \mathrm{kg}^{-1}$ respectively, with an average of $16.3 \pm 1.6 \mathrm{~Bq} \cdot \mathrm{kg}^{-1}$. While the maximum and minimum values of surface exhalation rate were recorded to be $7.35 \pm 0.49 \mathrm{~Bq} \cdot \mathrm{m}^{-2} \cdot \mathrm{h}^{-1}$ and $0.84 \pm 0.09$
Bq. $\mathrm{m}^{-2} \cdot \mathrm{h}^{-1}$, with an average of $3.50 \pm 0.35 \mathrm{Bqm}^{-2} \cdot \mathrm{h}^{-1}$. The maximum and minimum values of mass exhalation rates are found to be between $148 \pm 10 \mathrm{mBq} \cdot \mathrm{kg}^{-2} \cdot \mathrm{h}^{-1}$ and $17 \pm 2$ $\mathrm{mBq} \cdot \mathrm{kg}^{-2} \cdot \mathrm{h}^{-1}$, with an average of $70 \pm 7 \mathrm{mBq} \cdot \mathrm{kg}^{-2} \cdot \mathrm{h}^{-1}$.

Fig. 3 presents the radium concentration with respect to the sampling locations inside the town. The higher recorded values for radium concentration, surface and mass exhalation rates throughout the studied locations in Kassala town were found in location 12 (Alkhatmia), this may be due to that, this area is located along Al-Gash river bank very close to granitic formations of Kassala mountains (Kassala granitic hills) hence its soil is classified as being belonged to river terrace soils, in addition, granites are known to contain high uranium content and thus the originated soils. Beside that the soils of this area are noticed to be containing a large amounts of suspended material (sedimentary deposits) that, re-sediments as silt clay, sandy clay, and sand and gravel $[22,33]$.

The minimum value of radium concentration, surface and mass exhalation rates were recorded in location 11 (The popular market), this may be attributed to that the soil of this region is noticed to be as an agricultural soil with some grasses and trees, the soil is also classified as sandy soil, this may minimize the concentration values $[9,22]$.

Having close observation at Table 2 which compares values from different regions in Sudan and other Countries, the average values of radium concentration and radon exhalation rates (surface and mass) obtained here is lower than that reported from Saudi Arabia [7], Singa and Rabak towns, Sudan [15], Ethiopia [34], higher than the recorded values for Bulandshahr district, Uttar Pradesh-India [35], Egyp [36], Karbi Anglong district of Assam-India [37] and nearer to the values reported from India [38].

The observed values of radium concentration in soil samples in the present study are less than the recommended action level 370 Bq.kg-1 OECD, 1979 [39]. Report by a group of experts of the OECD Nuclear Energy Agency OECD Paris, France, and also lower than the average global value of 30 Bq. $\mathrm{kg}^{-1}[40]$. The soil of the study area is advisable to use in brick manufacturing for building construction.

Figs. 4 and 5. representing the surface and mass exhalation rates of radon gas from soil samples vs. radium concentration for Kassala town.

The correlation between the radium concentration and the radon exhalation rates of the source material is studied. A positive correlation has been observed between radium concentration and area exhalation rate in soil of the study area. The relationship between the concentration values of radium

\begin{tabular}{|c|c|c|c|c|c|}
\hline Location in Kassala town & No of samples & $(\rho \pm \Delta \rho) \times 10^{3}$ tracks per $\mathrm{cm}^{2}$ & $\begin{array}{l}\left(C_{\mathrm{Ra}} \pm \Delta \mathrm{E}_{\mathrm{A}}\right) \\
\mathrm{Bq} \cdot \mathrm{kg}^{-1}\end{array}$ & $\begin{array}{l}\left(E_{\mathrm{A}} \pm \Delta \mathrm{E}_{\mathrm{A}}\right) \\
\mathrm{Bq} \cdot \mathrm{m}^{-2} \cdot \mathbf{h}^{-1}\end{array}$ & $\begin{array}{l}\left(E_{M} \pm \Delta E_{M}\right) \\
m B q \cdot k^{-2} \cdot h^{-1}\end{array}$ \\
\hline Location 1 (Al-Halanga Alberno) & 14 & $315.45 \pm 39.06$ & $18.8 \pm 2.3$ & $4.05 \pm 0.50$ & $81 \pm 10$ \\
\hline Location 2 (Northern AlHalnga) & 17 & $272.80 \pm 28.93$ & $16.3 \pm 1.7$ & $3.50 \pm 0.37$ & $70 \pm 7$ \\
\hline Location 3 (Almerghania) & 14 & $89.42 \pm 7.65$ & $5.3 \pm 0.5$ & $1.15 \pm 0.10$ & $23 \pm 2$ \\
\hline
\end{tabular}
and the exhalation rates (surface and mass) are shown to be linear.

Table 1. Values of radon, radium concentrations, radon exhalation rates from soil samples at Kassala town, Sudan. 


\begin{tabular}{|c|c|c|c|c|c|}
\hline Location in Kassala town & No of samples & $(\rho \pm \Delta \rho) \times 10^{3}$ tracks per $\mathrm{cm}^{2}$ & $\begin{array}{l}\left(C_{\mathrm{Ra}} \pm \Delta \mathrm{E}_{\mathrm{A}}\right) \\
\mathrm{Bq} \cdot \mathrm{kg}^{-1}\end{array}$ & $\begin{array}{l}\left(E_{A} \pm \Delta E_{A}\right) \\
B q \cdot m^{-2} \cdot h^{-1}\end{array}$ & $\begin{array}{l}\left(E_{M} \pm \Delta E_{M}\right) \\
m B q \cdot k^{-2} \cdot h^{-1}\end{array}$ \\
\hline Location 4 (Almurbaat) & 17 & $93.69 \pm 10.95$ & $5.6 \pm 0.7$ & $1.20 \pm 0.14$ & $24 \pm 3$ \\
\hline Location 5 (Alturaa) & 18 & $238.08 \pm 18.67$ & $14.2 \pm 1.1$ & $3.06 \pm 0.24$ & $61 \pm 5$ \\
\hline Location 6 (Alkara) & 14 & $190.48 \pm 23.56$ & $11.4 \pm 1.4$ & $2.45 \pm 0.30$ & $49 \pm 6$ \\
\hline Location 7 (College of Medicine) & 14 & $267.98 \pm 25.14$ & $16.0 \pm 1.5$ & $3.44 \pm 0.32$ & $69 \pm 6$ \\
\hline Location 8 (Northern Alswagi) & 14 & $328.53 \pm 34.51$ & $19.6 \pm 2.1$ & $4.22 \pm 0.44$ & $85 \pm 9$ \\
\hline Location 9 (Alummal neighborhood) & 14 & $145.43 \pm 24.04$ & $8.7 \pm 1.4$ & $1.87 \pm 0.31$ & $38 \pm 6$ \\
\hline Location 10 (Banat) & 14 & $378 \pm 33.55$ & $22.6 \pm 2.0$ & $4.86 \pm 0.43$ & $98 \pm 9$ \\
\hline Location 11 (The popular market) & 14 & $65.38 \pm 7.23$ & $3.9 \pm 0.4$ & $0.84 \pm 0.09$ & $17 \pm 2$ \\
\hline Location 12 (Alkhatmia) & 17 & $572.68 \pm 37.82$ & $34.2 \pm 2.3$ & $7.35 \pm 49$ & $148 \pm 10$ \\
\hline Location 13 (Southern Alswagi) & 14 & $449.09 \pm 49.67$ & $26.8 \pm 3.0$ & $5.76 \pm 0.64$ & $116 \pm 13$ \\
\hline Location 14 (Al-Gash river) & 14 & $411.27 \pm 44.71$ & $24.6 \pm 2.7$ & $5.28 \pm 0.57$ & $106 \pm 12$ \\
\hline Average & 209 & $272.79 \pm 27.54$ & $16.3 \pm 1.6$ & $3.50 \pm 0.35$ & $70 \pm 7$ \\
\hline
\end{tabular}

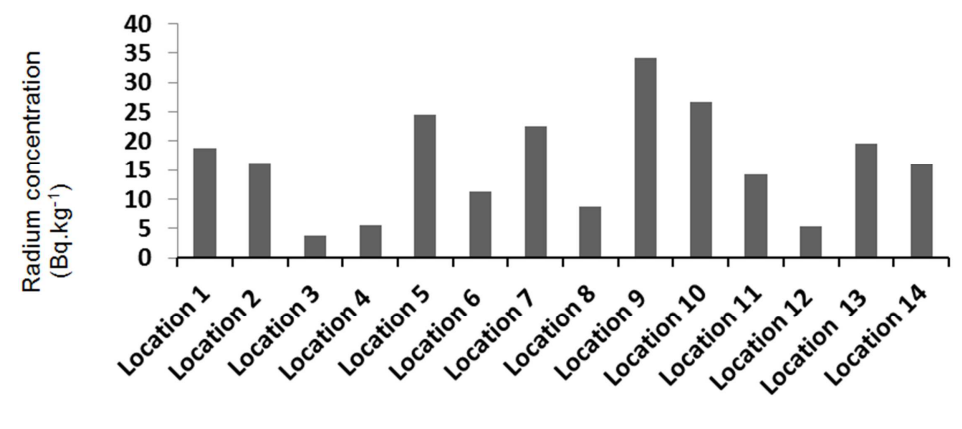

Sampling Locations in Kassala Town.

Figure 3. Radium concentration with respect to the study area at Kassala town.

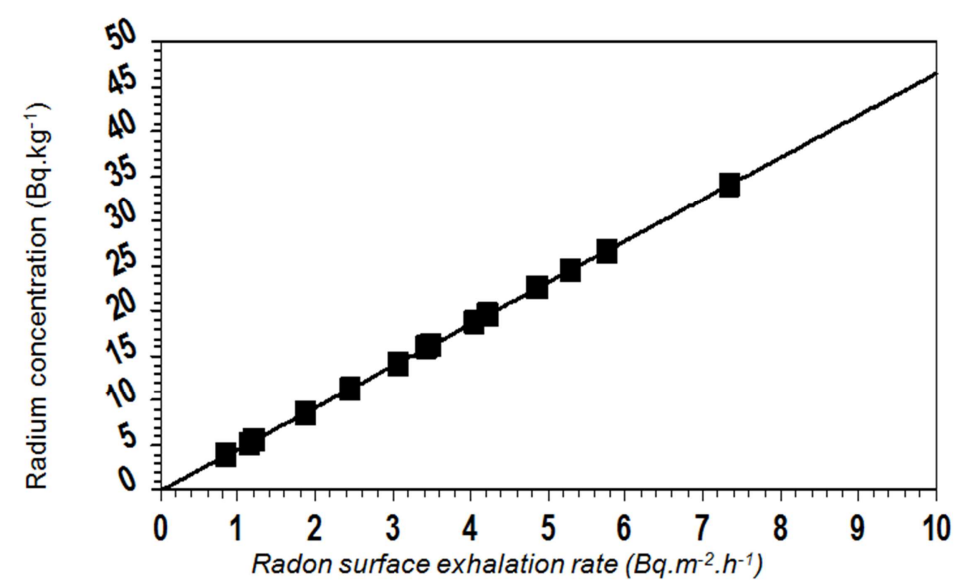

Figure 4. Surface exhalation rate vs. radium concentration for soil samples at Kassala town.

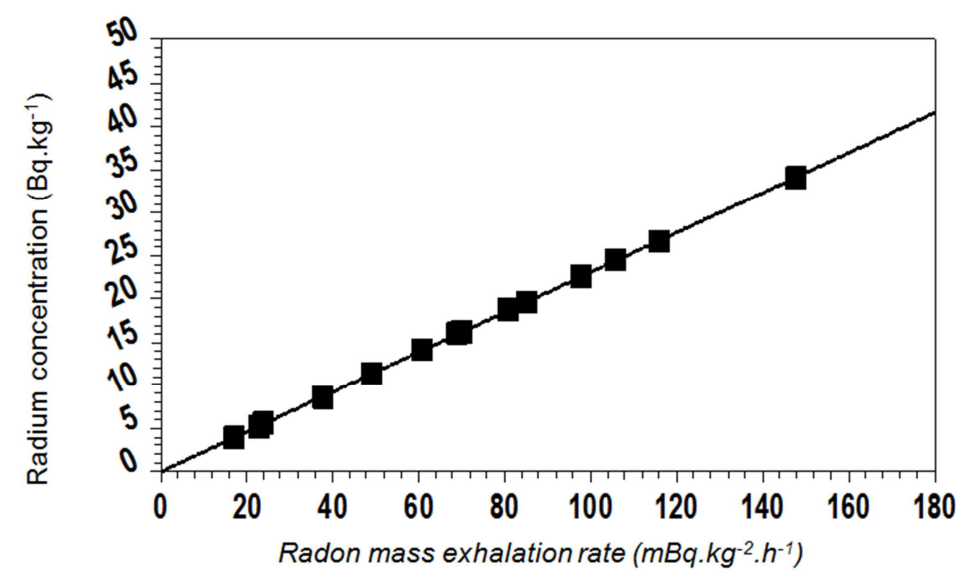

Figure 5. Mass exhalation rate vs. radium concentration for soil samples at Kassala town. 
Table 2. Values of concentration and exhalation rates of radon and radium concentration in different countries as compared with our study.

\begin{tabular}{|c|c|c|c|c|}
\hline Country & $\mathrm{C}\left(\mathrm{Bq} \cdot \mathrm{kg}^{-1}\right)$ & $E_{A}\left(B q \cdot m^{-2} \cdot h^{-1}\right)$ & $E_{M}\left(m B q \cdot k^{-2} \cdot h^{-1}\right)$ & Reference \\
\hline Saudi Arabia & 33 & 8.4 & 251 & [7] \\
\hline Rabak Sudan & 34 & 7.2 & 145 & {$[15]$} \\
\hline Singa, Sudan & 82 & 17.6 & 354 & {$[15]$} \\
\hline Ethiopia & 40.2 & - & - & [34] \\
\hline Bulandshahr district, Uttar Pradesh, India & 14.1 & 0.60 & 23.1 & {$[35]$} \\
\hline Egypt & $11.3-74.4$ & $0.29-0.95$ & - & {$[36]$} \\
\hline India & 19.6 & 0.76 & 23 & {$[38]$} \\
\hline Kassala, Sudan & 16.3 & 3.5 & 70 & This study \\
\hline
\end{tabular}

\section{Conclusion}

The can technique containing CR-39 plastic track detectors have been used for the measurement of radium concentration, surface and mass radon exhalation rates in soil samples collected from various locations from Kassala town in Sudan. Radium concentration in soil samples varies from 3.9 to 34.2 Bq. $\mathrm{kg}^{-1}$, with an average of $16.3 \pm 1.6 \mathrm{~Bq} \cdot \mathrm{kg}^{-1}$ for the various locations in the town. The surface and mass exhalation rates of radon from these samples has been found to vary from 0.84 to $7.35 \mathrm{~Bq} \cdot \mathrm{m}^{-2} \cdot \mathrm{h}^{-1}$ and 17 to $148 \mathrm{mBq} \cdot \mathrm{kg}^{-1} \cdot \mathrm{h}^{-1}$, with an averages of $3.50 \pm 0.35 \mathrm{~Bq} \cdot \mathrm{m}^{-2} \cdot \mathrm{h}^{-1}$ and $70 \pm 7 \mathrm{mBq} \cdot \mathrm{kg}^{-1} \cdot \mathrm{h}^{-1}$, respectively for the studied soil samples. The values of radium concentration obtained from the study are found to be linearly dependent with exhalation rates. The measured values were compared with others all over the world.

\section{Acknowledgment}

The authors would like to express thanks to the residents of the study areas for their cooperation during the fieldwork. The authors are thankful to Kassala University for support and cooperation in this study.

\section{References}

[1] B. Al-Bataina, and Abd Elmoniem A. Elzain "Seasonal Variation of Indoor Radon-222 Concentration Levels in Zarqa City, Jordan". Abhath Al-Yarmouk "Basic Sci. \& Eng.” (2003), 12(1), pp. 191-202.

[2] K. A. korany, M. S. El Nnagdy, S. F. Hassan, A. Shata, "Study of Radiation Hazards Indices and Radon Exhalation Rate in Soil Samples from Wadi Naseib Area, Sinai, Egypt", International Journal of Advanced Research in Physical Science (IJARPS), (2014), 4, pp. 7-15.

[3] Abd Elmoniem A. Elzain, A. K. Sam, "Sudan Report to the Third Co-Ordination Meeting of the Project on: Measurement of indoor Radon Concentration in some Cities in Arab countries." Arab Atomic Energy Agency - Egyptian Atomic Energy Agency - Egypt - Cairo. 22-23/11/2005.

[4] Abd-Elmoniem A. Elzain, "A Study of Indoor Radon Levels and Radon Effective Dose in Dwellings of Some Cities of Gezira State in Sudan", Nuclear Technology and Radiation Protection, (2014), 29(4), pp. 307-312.
[5] Abd-Elmoniem A. Elzain, "Assessment of Indoor Radon Doses Received by the Students and Staff in Schools in Some Towns in Sudan", International Journal of Science and Research (IJSR), (2015), 4(1), pp. 2566-2571.

[6] Abd-Elmoniem A. Elzain, "Indoor Radon Levels in Different Types of Rooms and Building Materials.", in the $2^{\text {nd }}$ International Conference On Radon in the Environment 2015", Krakow, Jordan Congress Bureau, Galaxy Hotel, POLAND, (2015), 25-29 May, 2015.

[7] S. M. Farid, "Indoor Radon in Dwellings of Jeddah City, Saudi Arabia and its Correlations With the Radium and Radon Exhalation Rates from Soil", Indoor and Built Environment, (2016), 25(1), pp. 269-278.

[8] H. Idriss, I. Salih, Abdulaziz S. Alaamer, M. Y. Abdelgalil, Salih Ali Salih, Amna M. Hasan, Mohammed A. ELtahir, Mustafa M. O. Ahamed "Study of Radon in Soil Gas, Trace Elements and Climatic Parameters Around South Kordofan State, Sudan", Environ Earth Sci., (2014), 72(2), pp. 335-339.

[9] Abd Elmoniem A. Elzain, "Radon Exhalation Rates from Some Building Materials Used in Sudan" Indoor and Built Environment, (2015), 24(6), pp. 852-860.

[10] Abd-Elmoniem A. Elzain, "Estimation of Soil Gas Radon Concentration and the Effective Dose Rate by Using SSNTDs", International Journal of Science and Research Publications (IJSRP), (2015), 5(2); pp. 3887-3891.

[11] M. S. Khan, A. H. Naqvi, A. Azam and D. S. Srivastava., "Radium and Radon Exhalation Studies of Soil", Iran J Radiat Res., (2011), 8(4): pp. 207-210.

[12] Abd-Elmoniem A. Elzain, "Dose Assessment to Inhalation Exposure of Indoor Radon in Sudan using SSNTDS", in the $4^{\text {th }}$ International Conference On Radiation and Applications in Various Fields of Research - RAD 2016, Faculty of Electronic Engineering - Nis - Serbia (2016), 23-27 May, 2016.

[13] A. Azam, A. H. Naqvi, D. S. Srivastava, "Radium Content and Radon Exhalation Measurement Using LR-115 type II Plastic Track Detectors", Nucl. Geophys, (1995), 9(6), pp. 653-657.

[14] Rohit Mehra, Surinder Singh, and Kulwant Singh, "A Study of Uranium, Radium, Radon Exhalation Rate and Indoor Radon in the Environs of Some Areas of the Malwa Region, Punjab", Indoor and Built Environment, (2006), 15: pp. 499.

[15] Abd-Elmoniem A. Elzain, Y. Sh. Mohammed, Kh. Sh. Mohammed, Sumaia S. M, "Radium and Radon Exhalation Studies in Some Soil Samples from Singa and Rabak Towns, Sudan using CR-39", International Journal of Science and Research (IJSR), (2014), 3 (11), pp. 632-637. 
[16] Abd Elmoniem A. Elzain, A. K. Sam, O. M. Mukhtar, M. A. Abbasher, "A Survey of Indoor Radon - 222 Concentration Measurements in Kassala Town", Gezira Journal of Engineering \& Applied Sciences, (2008), 3(2), pp. 72-100.

[17] O. M. Mukhtar, Abd Elmoniem A. Elzain, Radon Mmonitoring at Khartoum Using the Charcoal Technique. Abhath Al-Yrmouk "Basic Sci. \& Eng”. (2006), 15(2), pp. 225-235.

[18] Abd Elmoniem A. Elzain, "Indoor Radon - 222 Concentrations in Some Cities in Kassala State, Eastern Sudan", In Proceedings of the 2011 International AASRT Symposium, Orlando, Florida, U.S.A., (2011), (2), pp. 71-84.

[19] Abd Elmoniem A. Elzain, "Seasonal Variation of Radon - 222 Concentration in Shops and Pharmacies of Alzarqa TownJordan", In Proceedings of the 2011 International AASRT Symposium, Orlando, Florida, U.S.A., (2011), (2), pp. 38-45.

[20] Abd-Elmoniem A. Elzain, "Indoor Radon Concentrations in Rufaa and Al-Hasahisa Towns in the Central Part of Sudan", in the $3^{\text {rd }}$ International Conference On Radiation and Applications in Various Fields of Research - RAD 2015, Slovenska Plaza, Budva, Montenegro, (2015), 8-12 June, 2015.

[21] Abd-Elmoniem A. Elzain, "Radon in Workplaces in Khartoum town, Capital of Sudan", in the $3^{\text {rd }}$ International Conference On Radiation and Applications in Various Fields of Research RAD 2015, Slovenska Plaza, Budva, Montenegro, (2015), 8-12 June, 2015.

[22] Abd Elmoniem A. Elzain, A. K. Sam, O. M. Mukhtar and M. A Abbasher "Measurements of Radon Gas Concentration in a Soil at Some Towns in Kassala State." Gezira Journal of Engineering \& Applied Sciences, (2009), 4(1), pp. 15-42.

[23] Abd-Elmoniem A. Elzain, "Determination of Soil Gas Radon Concentration from Some Locations of Gedarif Town, Sudan by Using CR-39", in the $3^{\text {rd }}$ International Conference in Energy Challenges and Mechanics (ECM3) - towards a big picture, Aberdeen, Scotland, UK, (2015), 7-9, July, 2015.

[24] Abd-Elmoniem A. Elzain, "Determination of Radium Concentration and Radon Exhalation Rate in Soil Samples Using CR-39", Advances in Applied Science Research, (2015) 6(2), pp. 92-102.

[25] Abd Elmoniem A. Elzain, "Measurement of Radon-222 Concentration Levels in Water Samples in Sudan "Advances in Applied Science Research, (2014), 5(2), pp. 229-234.

[26] Abd Elmoniem A. Elzain, "A Study on the Radon Concentrations in Drinking Water in Kassala State (Eastern Sudan) and the Associated Health Effects", World Applied Sciences Journal, (2014), 31(3), pp. 367-375.

[27] F. Abu-Jarad, "Application of Nuclear Track Etch Detector for Radon Related Measurements", Nucl. Track Radiat. Meas. J., (1988), 15, pp. 525-534.

[28] H. W. Alter and P. B. Price "Radon Detection Using Track Registration Material", US Patent, (1972), 3, pp. 665, 194 Terradex Corp, 1972.
[29] Mohamed Abd-Elzaher, "An Overview on Studying Rn-222 Exhalation Rates Using Passive Technique Solid-State Nuclear Track Detectors", American Journal of Applied Sciences, (2012), 9 (10), pp. 1653-1659.

[30] G. Somogyi "The Environmental Behavior of Radium", Technical Reports Series No. 310, vol. 1. IAEA, Vienna, (1990), pp. 229-256.

[31] G. Somogyi, A. Hafez, I. Hunyadi and M. Toth-Szilagyi, "Measurement of Exhalation and Diffusion Parameters of Radon in Solids by Plastic Track Detectors", Nucl. Tracks Radiat. Meas., (1986), 12(1-6), pp. 701-704.

[32] D. M. B. Baruah, P. C. Deka, M. Rahman, "Measurement of Radium Concentration and Radon Exhalation Rate in Soil Samples Using SSNTDs", The African Review of Physics, (2013), 8(32), pp. 215-218.

[33] M. E. M, "Water Resources Assessment Kassala Gash Basin. The Democratic Republic of the Sudan", Ministry of Energy and Mining (M. E. M.), National Administration, The Kingdom of the Netherlands, Ministry of International Corporation, Groundwater Survey, (1982), Final Technical Report, 1982.

[34] Sintie Welelaw, M. K. Bhardwaj, "Assessment of Hazards Due to Radon's Mass and Surface Exhalation Rates; and Radium Content in Soil Samples of Lalibela, Ethiopia", I. J. E. M. S., (2013), 4 (4), pp. 445-448.

[35] M. Zubair, M. Shakir Khan, D. Verma, "Measurement of Radium Concentration and Radon Exhalation Rates of Soil Samples Collected from Some Areas of Bulandshahr District, Uttar Pradesh, India Using Plastic Track Detectors", Iran. J. Radiat. Res., (2012), 10(2), pp. 83-87.

[36] Hesham A. Youssef, A. A. Embaby, A. H. El-Farrash and H. A. Laken, "Radon Exhalation Rate in Surface Soil of Graduate's Villages in West Nile Delta, Egypt, Using Can Technique", International Journal of Recent Scientific Research, (2015), 6 (4), pp. 3440-3446

[37] Ranjan Kr. Kakatia, Lukendra Kakatib and T. V. Ramachandran, "Measurement of Uranium, Radium and Radon Exhalation Rate of Soil Samples from Karbi Anglong District of Assam, India Using EDXRF and Can technique Method", APCBEE Procedia., (2013), 5, pp. 186-191.

[38] B. P. Singh, B, Pandit, V, N, Bhardwaj, Paramjit Singh, Rajesh Kumar, "A study of Radium and Radon Exhalation Rate in Some Solid Samples Using Solid State Nuclear Track Detectors", Indian Journal of Pure \& Applied Physics, (2010), 48, pp. 493-495.

[39] (OECD) Organization for Economic Cooperation and Development. In: Exposure to Radiation from Natural Radioactivity in Building Materials. Report by a group of Experts of the OECD Nuclear Energy Agency, OECD, Paris, France, 1979.

[40] UNSCEAR, United Nations Scientific Committee on the Effects of Atomic Radiations, United Nations, New York, 1993. 